\begin{tabular}{|l|l|l|}
\hline \multicolumn{2}{|c|}{ PublisherInfo } \\
\hline \hline PublisherName & $:$ & BioMed Central \\
\hline \hline PublisherLocation & $:$ & London \\
\hline \hline PublisherImprintName & $:$ & BioMed Central \\
\hline \hline
\end{tabular}

\title{
Tandem repeats take, make shape
}

\begin{tabular}{|l|l|l||}
\hline \multicolumn{2}{|c|}{ ArticleInfo } \\
\hline \hline ArticleID & $:$ & 5022 \\
\hline \hline ArticleDOI & $:$ & $10.1186 /$ gb-spotlight-20041215-01 \\
\hline \hline ArticleCitationID & $:$ & spotlight-20041215-01 \\
\hline \hline ArticleSequenceNumber & $:$ & 85 \\
\hline \hline ArticleCategory & $:$ & Research news \\
\hline ArticleFirstPage & $:$ & 1 \\
\hline \hline ArticleLastPage & $:$ & 3 \\
\hline \hline & & RegistrationDate : 2004-12-15 \\
ArticleHistory & $:$ & OnlineDate \\
\hline \hline ArticleCopyright & $:$ & BioMed Central Ltd2004 12-15 \\
\hline \hline ArticleGrants & $:$ & \\
\hline \hline ArticleContext & $:$ & 130595511 \\
\hline \hline
\end{tabular}


Melissa Phillips

Email: mlphilli@u.washington.edu

Tandem repeats of sequences in developmental genes may contribute to morphological evolution, according to a paper in this week's Proceedings of the National Academy of Sciences USA. John W. Fondon, III, and Harold R. Garner of the University of Texas, Southwestern, show that different lengths of coding repeats in dogs correlate with morphological differences in the dogs' skulls and limbs (Proc Natl Acad Sci USA 2004, 10.1073/pnas.0408118101). They also show that many other animals including humans - have similar repeat length variation in their developmental genes .

The paper "seems to give a functional meaning to a kind of variation that we knew existed for a long time," Günter Wagner of Yale University told us. But "there was the possibility that this was just a form of evolutionary junk," said Wagner, who was not involved in the study.

Fondon and Garner sequenced tandem repeats from 92 breeds of dogs. They chose 37 repeat sequences from 17 canine developmental genes, mostly transcription factors. They found at least two alleles of different lengths for 15 of the 17 genes, and five genes exist in 12 or more variations.

One of most dramatic polymorphisms, a 51 base-pair deletion in the transcription factor Alx-4 (aristaless-like homeobox 4), was found on both chromosomes of four Great Pyrenees dogs. All four dogs had polydactyly - the presence of an extra digit - at the first digit of their rear paws. None of the other breeds had either polydactyly or a deletion at this locus. They also found that one Great Pyrenees dog without polydactyly was also homozygous for the normal, full-length $A l x-4$ allele. "That was the nail in the coffin for any doubt we had that this phenotype is indeed being caused by this repeat contraction," Fondon said.

Fondon and Garner also looked more closely at Runx-2 (runt-related transcription factor 2), which regulates osteoblast differentiation. They found that it encodes 18-20 glutamines followed by 12-17 alanines and is highly polymorphic among breeds. Following previous reports hinting that strings of glutamine residues drive transcription while polyalanines repress it, the researchers measured the ratio of the two amino acids in each allele, Fondon said. The glutamine-to-alanine ratio in Runx-2 correlated significantly with two craniofacial measurements in the dogs: the length of the midface and the angle at which the nose bends.

Repeat expansion and contraction is "a very useful mechanism for imposing rapid evolution," Fondon told us. Tandem repeat units can be added or subtracted by slipped-strand mispairing during DNA replication. This type of mutation happens at least 100,000 times as often as simple point mutations, Fondon said. Also, he added, repeat length changes can make subtle alterations to proteins, whereas point mutations are usually either neutral or fatal to the protein.

A lack of effective point mutations might impede evolution over a few hundred years, but probably not over tens of millions of years, according to Greg Wrayof Duke University. "I think it's a mistake to think that evolution requires special kinds of mutations," said Wray, who was not involved in the study.

The authors also genotyped coding repeats from three genes - Runx-2, Dlx-2, and Twist-1 in other species, including wolves, river otters, cottontail rabbits, silver-haired bats, and humans. They found 
repeat polymorphisms in at least one of the repeats in every species, which suggests that tandem repeat lengths may also control morphology in these species, Fondon said.

According to Wagner, however, it's unlikely that repeat expansions and contractions contribute greatly to developmental morphology in animals other than amniotes. "You don't see tandem repeats at these levels in developmental genes of fish and amphibians," Wagner said. This mechanism "could eventually explain why mammals are so evolvable - because they have another source of genetic variation."

"I think most people carry around a model where one amino acid changes, and then the protein function changes," said Wray. "So this is kind of a wake-up call, saying, 'No, actually, repeat variation in a coding sequence might be a more important part of the genetics of evolutionary change in morphology than we thought."'

\section{References}

1. Proceedings of the National Academy of Sciences USA, [http://www.pnas.org]

2. John W. Fondon, [http://innovation.swmed.edu/lab/fondon.htm]

3. Gunter Wagner, [http://pantheon.yale.edu/\%7Egpwagner/index.html]

4. Transcriptional activation modulated by homopolymeric glutamine and proline stretches

5. Evolution of a transcriptional repression domain in an insect Hox protein

6. Slipped-strand mispairing: a major mechanism for DNA sequence evolution

7. Greg Wray, [http://www.biology.duke.edu/wraylab/] 